\title{
Estrogen receptor alpha drives proliferation in PTEN-deficient prostate carcinoma by stimulating survival signaling, MYC expression and altering glucose sensitivity
}

Itsuhiro Takizawa ${ }^{1, *}$, Mitchell G. Lawrence ${ }^{1, *}$, Preetika Balanathan ${ }^{1}$, Richard Rebello ${ }^{1}$, Helen B. Pearson 2,3, Elika Garg4,5, John Pedersen 6 , Normand Pouliot ${ }^{2,3}$, Robert Nadon ${ }^{5}$, Matthew J. Watt ${ }^{7}$, Renea A. Taylor ${ }^{7}$, Patrick Humbert ${ }^{2,3,8}$, Ivan Topisirovic $^{4}$, Ola Larsson ${ }^{9}$, Gail P. Risbridger ${ }^{1}$ and Luc Furic ${ }^{1}$

${ }^{1}$ Department of Anatomy and Developmental Biology, Monash University, Clayton, Victoria, Australia

2 Peter MacCallum Cancer Centre, Melbourne, Victoria, Australia

${ }^{3}$ Sir Peter MacCallum Department of Oncology, Melbourne University, Victoria, Australia

${ }^{4}$ Lady Davis Institute for Medical Research, Sir Mortimer B. Davis-Jewish General Hospital and Departments of Oncology, Experimental Medicine and Biochemistry, McGill University, Montréal, Canada

${ }^{5}$ Department of Human Genetics, McGill University, Montréal, Canada

${ }^{6}$ TissuPath Pathology, Melbourne, Victoria, Australia

7 Department of Physiology, Monash University, Clayton, Victoria, Australia

8 Department of Pathology and Department of Biochemistry and Molecular Biology, the University of Melbourne, Parkville, Australia

${ }^{9}$ Department of Oncology-Pathology, Karolinska Institutet, Stockholm, Sweden

* These authors contributed equally to this work

Correspondence to: LuC Furic, email: Iuc.furic@monash.edu

Gail P. Risbridger, email: gail.risbridger@monash.edu

Keywords: Estrogen receptor alpha, prostate cancer, PTEN, metabolism, MYC

Received: October 20,2014 Accepted: November 25, $2014 \quad$ Published: November 26, 2014

This is an open-access article distributed under the terms of the Creative Commons Attribution License, which permits unrestricted use, distribution, and reproduction in any medium, provided the original author and source are credited.

\section{ABSTRACT}

While high doses of estrogen, in combination with androgens, can initiate prostate cancer ( $\mathrm{PCa}$ ) via activation of the estrogen receptor a (ERa), the role of ERa in PCa cells within established tumors is largely unknown. Here we show that expression of ERa is increased in high grade human PCa. Similarly, ERa is elevated in mouse models of aggressive PCa driven by MYC overexpression or deletion of PTEN. Within the prostate of PTEN-deficient mice, there is a progressive pattern of ERa expression: low in benign glands, moderate in tumors within the dorsal, lateral and ventral lobes, and high in tumors within the anterior prostate. This expression significantly correlates with the proliferation marker Ki67. Furthermore, in vitro knockdown of ERa in cells derived from PTEN-deficient tumors causes a significant and sustained decrease in proliferation. Depletion of ERa also reduces the activity of the PI3K and MAPK pathways, both downstream targets of non-genomic ERa action. Finally, ERa knockdown reduces the levels of the MYC protein and lowers the sensitivity of cellular proliferation to glucose withdrawal, which correlates with decreased expression of the glucose transporter GLUT1. Collectively, these results demonstrate that ERa orchestrates proliferation and metabolism to promote the neoplastic growth of PCa cells. 


\section{INTRODUCTION}

Prostate cancer is the second leading cause of cancer-related death in US men; 1 in 7 men will be diagnosed in their lifetime and 1 in 37 will die from prostate cancer [1]. Androgens are the main regulators of prostatic cell proliferation in development and homeostasis. Androgens and the androgen receptor (AR) also drive the progression of prostate cancer, although the disease is often diagnosed at an age when the serum level of testosterone in men is declining [2]. Nevertheless, prostate cancer is an endocrine-related cancer where androgens are necessary, but insufficient, to cause cancer development and progression [3]. Yet, combined treatment of mice or benign human xenografts with high levels of testosterone and estradiol induces prostate carcinogenesis $[4,5]$. This demonstrates that along with androgens, estrogens have a critical role in prostate cancer.

Estrogens regulate proliferation and cell death in the prostate and have dual roles in prostate cancer, either pro- or anti-tumorigenic. These specific actions are mediated by the two estrogen receptor (ER) subtypes, $\mathrm{ER} \alpha$ or ER $\beta$ [6]. The anti-tumorigenic role of ER $\beta$ has been studied in detail [7]. Specific activation of ER $\beta$ with selective agonists causes apoptosis, decreases tumor growth in vivo and inhibits epithelial-to-mesenchymal transition [8-10]. The pro-tumorigenic actions of ER $\alpha$ are comparatively ill-defined. One explanation for the paucity of research into ER $\alpha$ in prostate cancer is the uncertainty about its expression profile; ER $\alpha$ is abundantly expressed in normal and tumor stroma, but there are differing reports about whether it is expressed in epithelial prostate cancer cells [11-17]. Most studies have detected negligible ER $\alpha$ staining in prostate cancer cells using immunohistochemistry. This could be due to an underrepresentation of high grade samples because other studies showed that ER $\alpha$ expression in prostate cancer cells is significantly associated with high Gleason score and poor patient survival $[11,17]$. A second reason that the role of $\mathrm{ER} \alpha$ in prostate cancer cells has been underestimated, is that most human prostate cancer cell lines express little or no ER $\alpha$ [18-22]. Therefore, the goal of this study was to resolve the expression profile of ER $\alpha$ in prostate cancer cells and identify new models to study its effects. By focusing on the autonomous role of ER $\alpha$ in prostate cancer cells, including interactions with other signalling pathways, we aimed to provide a more comprehensive understanding of estrogen action in prostate cancer.

The role of ER $\alpha$ in cancer cell proliferation and survival has been extensively studied in the breast and other female tissues such as the ovary, uterus and cervix. These studies demonstrate that $\mathrm{ER} \alpha$ is a multifunctional protein; in addition to its genomic role as a transcription factor, where agonist-bound $E R \alpha$ regulates the expression of downstream genes containing estrogen-response elements (ERE) [23], ER $\alpha$ localizes to the cell membrane via palmitoylation to direct "non-genomic" activities [24]. At the plasma membrane, ER $\alpha$ interacts with $\mathrm{c}-\mathrm{Src}$ and the regulatory subunit of PI3K, p85 $\alpha$, to augment signaling activity through the MAPK and PI3K pathways [25-27], both drivers of growth, proliferation and survival.

The interaction of ER $\alpha$ and survival signaling cascades is potentially significant because they are commonly dysregulated in prostate cancer. The PTEN tumor suppressor is frequently lost through single or biallelic deletion, mutations and epigenetic silencing [28, 29]. PTEN insufficiency promotes hyperactivation of the kinase AKT, leading to pro-survival and pro-proliferative signaling. Moreover, loss of PTEN synergizes with loss of p53, over-expression of MYC and sustained activation of MAPK in promoting prostate cancer initiation and progression [30-32]. In our studies of mice with conditional PTEN knockout in the prostate epithelium $\left(\mathrm{PBiCre}^{+/} ; \mathrm{Pten}^{A f f}\right)$, we noted a marked up-regulation of $\mathrm{ER} \alpha$ expression during cancer progression. This led us to investigate estrogen signaling in the PTEN-deficient model.

Here we show, in the PTEN-deficient model of prostate cancer, that the expression of ER $\alpha$ (but not AR or ER $\beta$ ) is significantly increased in regions of tumors where cell proliferation is notably enhanced. In addition, in human prostate cancer specimens we demonstrate that $\mathrm{ER} \alpha$ expression is associated with regions of high Gleason score, indicative of more aggressive disease. Stable downregulation of ER $\alpha$ expression in cell lines derived from primary PTEN-deficient tumors induced a striking and sustained reduction in proliferation. Our results indicate that ER $\alpha$ promotes the proliferation in PTEN-deficient tumors by regulating MYC expression and glucose sensitivity.

\section{RESULTS}

\section{$E R \alpha$ is expressed in prostate cancer cells}

It is contentious whether ER $\alpha$ is expressed in prostate cancer cells or only the stroma $[11-13,17,22]$. This prompted us to re-examine ER $\alpha$ expression in prostate cancer using immunohistochemistry. It has been suggested that ER $\alpha$ is up-regulated in high grade disease [11], so we selected a cohort of Gleason score 9 specimens and a similar number of low grade Gleason score 6 tumors for comparison. As expected, AR was abundantly expressed in the epithelium in all samples (Supplementary Fig. 1 and Supplementary Table 1). ER $\alpha$ was expressed in $48 \%(10 / 21)$ of Gleason score 9 tumors, but no Gleason score 6 tumors $(0 / 15)$, consistent with a previous study (Fig. 1A and B) [11]. This increase in ER $\alpha$ expression in high grade human prostate cancer was statistically significant $(P=0.001)$. In the positive specimens, $10-80 \%$ 
(average $40 \%$ ) of all cancer cells exhibited prominent nuclear staining of ER $\alpha$ (Supplementary Table 1). These findings warranted further studies into the biological significance of ER $\alpha$ in prostate cancer. Most human epithelial prostate cancer cell lines, however, express little or no ER $\alpha$, so are inappropriate to study the autonomous role of $\mathrm{ER} \alpha$ [18-22]. To identify systems to study the biological significance of $\mathrm{ER} \alpha$, we therefore examined $\mathrm{ER} \alpha$ expression in mouse models of aggressive prostate cancer. Consistent with data from our human specimens, $\mathrm{ER} \alpha$ levels are increased in tumors from both Hi-MYC (Fig. 1D) and PTEN-deficient (Fig. 1F) mice when compared to normal prostate tissue from control mice (Fig. 1C and E). Collectively, these data show that ER $\alpha$ is expressed in epithelial cells in a subset of aggressive prostate cancers and indicate that a number of mouse models mirror this expression pattern.

\section{ERa expression correlates with Ki67 in PTEN- deficient murine prostate cancer}

Further analysis of $\mathrm{ER} \alpha$ immunoreactivity in the prostates of PTEN-deficient mice revealed particularly intense staining towards the periphery of the malignant foci. This resembled the band of Ki67positive proliferating cells that has previously been reported [33] and prompted us to investigate whether

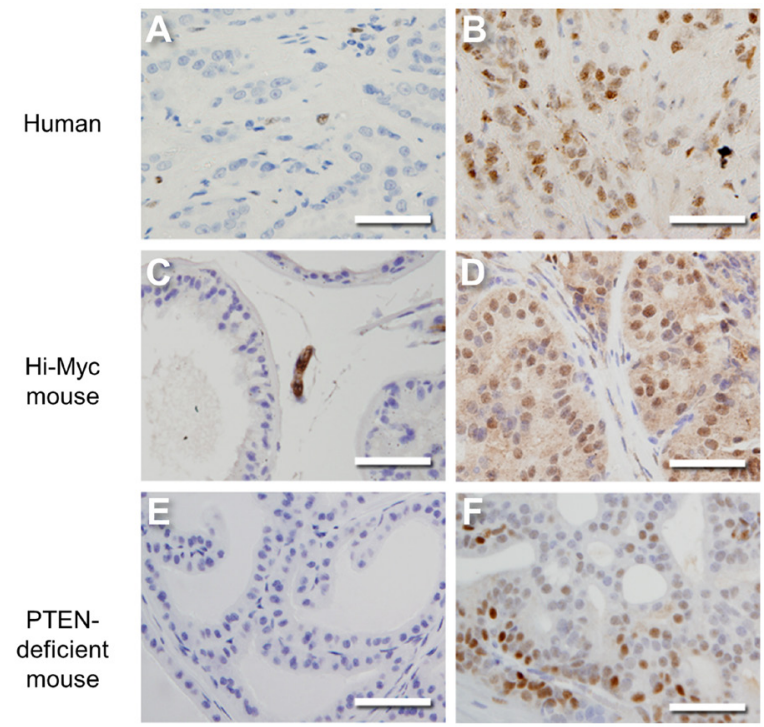

Figure 1: ERa expression increases in prostate cancer. Representative images of $\mathrm{ER} \alpha$ staining in human and mouse prostate cancer. Specimens of (A) Gleason score 6 and (B) Gleason score 9 human prostate cancer. (C) Benign lateral prostate tissue of a 5 month old control mouse (FVB) compared to (D) prostate cancer in an age-matched Hi-MYC mouse (ARR2/Pbsn-Myc). (E) Benign anterior prostate tissue from a 80-100 day old control mouse $\left(\mathrm{PBiCre}^{+/}\right)$compared to (F) malignant tissue in an age-matched PTEN-deficient animal $\left(\right.$ PBiCre $^{+-} ;$Pten $\left.^{\mathrm{t} / \mathrm{fl}}\right)$. Scale bars equal $50 \mu \mathrm{m}$.
$\mathrm{ER} \alpha$ and Ki67 levels correlate. To test this, staining was quantified in serial sections from four different zones of the prostate that have distinctive patterns of Ki67 expression (Supplementary Fig. 2A). The highest percentage of $\mathrm{Ki} 67$ and $\mathrm{ER} \alpha$ positive cells was in the peripheral region of anterior prostate (AP) tumors (Fig. $2 \mathrm{~A})$. In contrast, ER $\beta$ and AR staining did not vary across

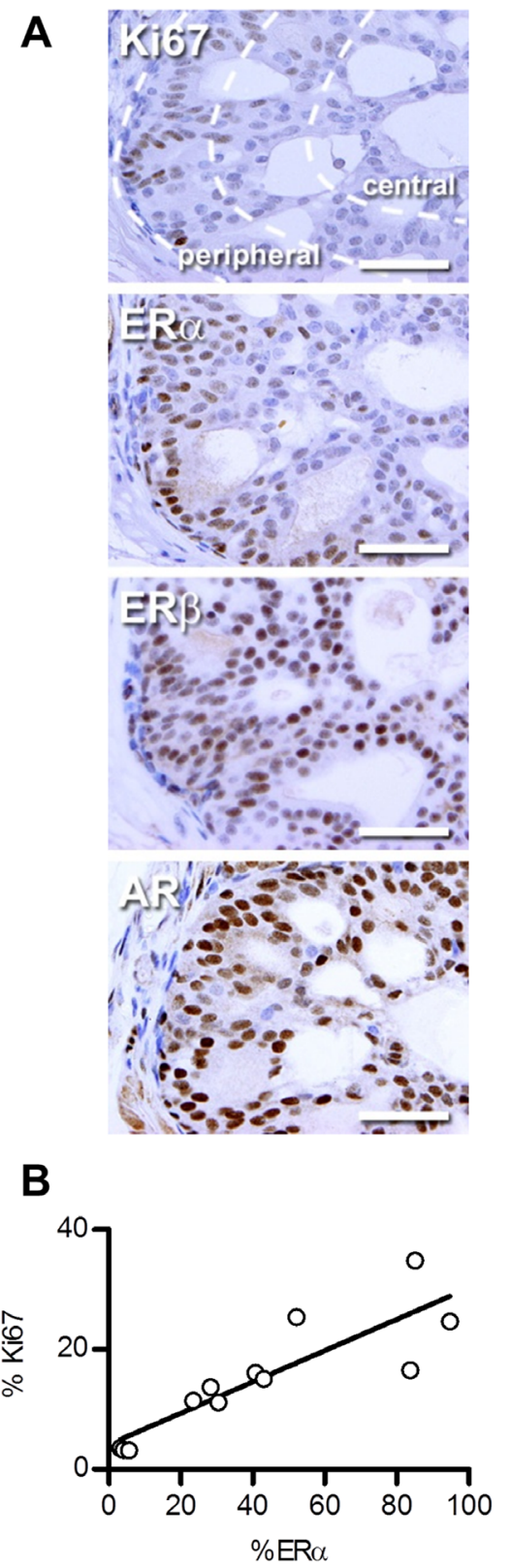

Figure 2: ER $\alpha$ expression correlates with proliferation in PTEN-deficient prostate cancer. (A) Representative images of immunohistochemical staining of Ki67, ER $\alpha, E R \beta$ and AR in the anterior prostate of 12-14 week old PTEN-deficient mice. The peripheral and central regions of the foci are shown in the Ki67 image. Scale bars $=50 \mu \mathrm{m}$. (B) Dot plot comparing the percentage of ER $\alpha$ and Ki67 positive cells in the prostate of PTEN-deficient mice $\left(P<0.001, \mathrm{r}^{2}=0.75\right.$, Pearson correlation, $\mathrm{n}=12$ regions from 3 mice). 
different regions (Fig. 2A and Supplementary Fig. 2B). Moreover, there were moderate levels of Ki67 and ER $\alpha$ staining in the central region of AP tumors and in tumors in the dorsal, lateral and ventral prostate (DLVP), but few cells stained in benign areas of the DLVP (Fig. 2A and Supplementary Fig. 2B). Both the differences in Ki67 and $\mathrm{ER} \alpha$ positive cells between regions (Supplementary Fig. $2 \mathrm{C}$ and $2 \mathrm{D}$ ) and the correlation between the proportion of $\mathrm{Ki} 67$ and ER $\alpha$ stained cells within the prostates of PTENdeficient mice (Fig. 2B) were statistically significant. The strong correlation between ER $\alpha$ and Ki67 staining implied that $\mathrm{ER} \alpha$ may regulate the proliferation of prostate cancer cells.

\section{ER $\alpha$ regulates proliferation}

We investigated whether ER $\alpha$ regulates proliferation using prostate cancer cells derived from the prostate of PTEN-deficient mice. These cells are epithelial, based

on the expression of epithelial rather than stromal phenotypic markers (Supplementary Fig. 3A and 3B). They also maintain AR expression (Supplementary Fig. 4A). Immunoblots confirmed that the PTEN-deficient cells also express abundant levels of full length ER $\alpha(E R \alpha 66)$ (Fig. 3A, lane 1) like MCF7 breast carcinoma cells, which were used as a positive control (Fig. 3A, lane 4). Treating the PTEN-deficient cells for 5 days with $1 \mu \mathrm{M}$ of TPSF, a non-competitive antagonist of $\mathrm{ER} \alpha$, reduced proliferation by $\sim 25 \%$ (Fig. 3B), similar to its effect on MCF7 cells [34]. There was no change in cell viability, showing that TPSF did not induce apoptosis (Supplementary Fig. 5). To confirm this finding, we also established PTEN-deficient cell lines stably expressing a non-targeting shRNA (shCtl) or an ER $\alpha$-specific $\operatorname{shRNA}(\operatorname{shER} \alpha)$. The shCtl cells expressed a similar amount of ER $\alpha$ compared to parental PTEN-deficient cells, while the shER $\alpha$ cells had a $\sim 70 \%$ reduction in the amount of $\mathrm{ER} \alpha$ (Fig. $3 \mathrm{~A}$, lane 2 and 3 and Supplementary Fig. 4B). We then compared the
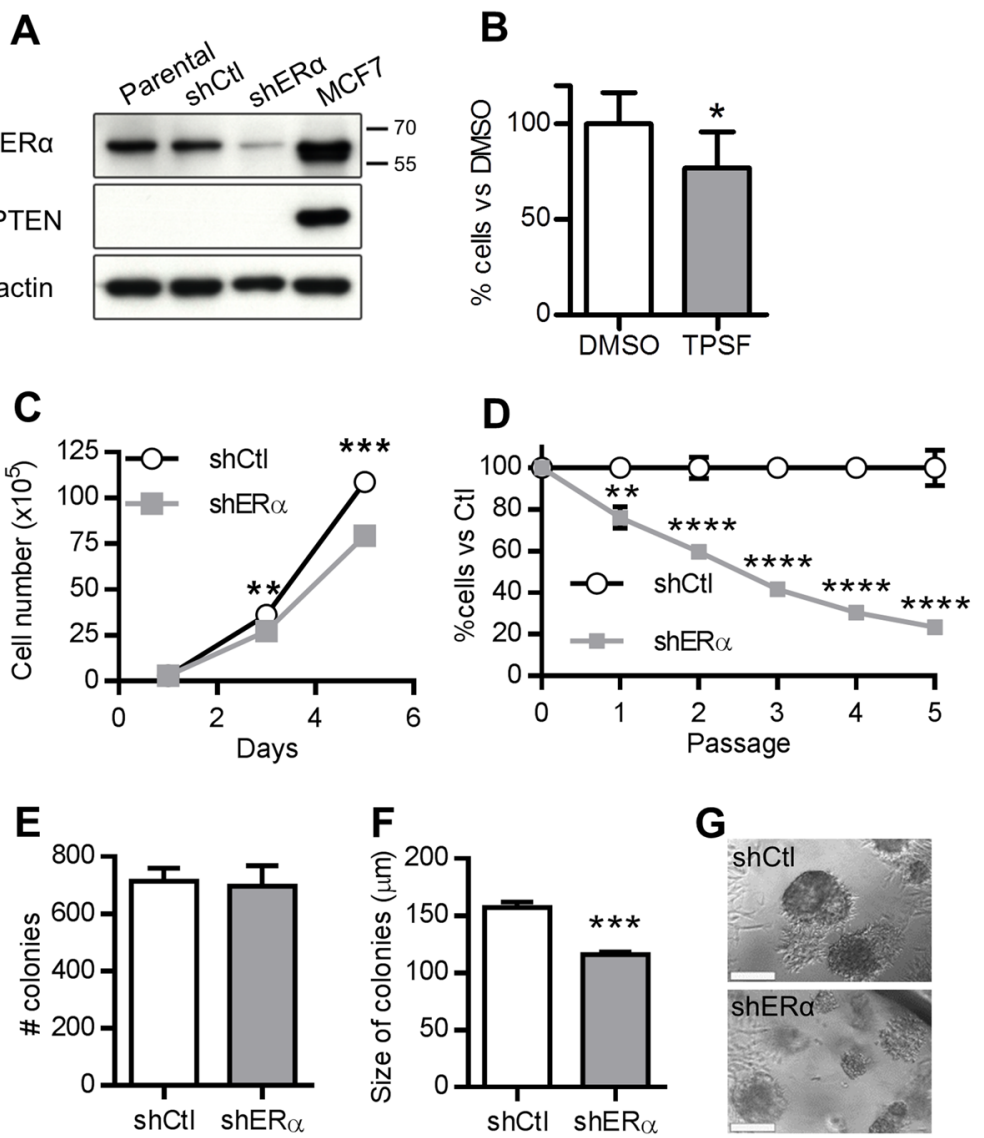

Figure 3: ER $\alpha$ knockdown inhibits the growth of PTEN-deficient prostate cancer cells. (A) Representative Western blots of ER $\alpha$, PTEN and pan-actin levels in parental (untransfected) PTEN-deficient prostate cancer cells and cells stably expressing non-silencing shRNA control (shCtl) or ER $\alpha$ shRNA ( $\operatorname{shER} \alpha$ ). MCF7 cells were used as a control for ER $\alpha$ and PTEN expression. (B) Relative percentage of cells after 5 days of treatment with DMSO or $1 \mu \mathrm{M}$ TPSF $(* P<0.05$, paired T Test, $\mathrm{n}=3)$. (C) Average number of shCtl and shER $\alpha$ cells after 1,3 and 5 days of culture $(* * P<0.01, * * * P<0.001,2$ Way ANOVA, $\mathrm{n}=3)$. (D) Average percentage of cells relative to the shCtl over 5 passages $(* * P<0.01, * * * * P<0.0001, \mathrm{n}=3$ flasks, two way ANOVA) Average number (E) and diameter (F) of colonies formed in Matrigel (*** $P<0.0001$, $\mathrm{t}$ test, $\mathrm{n}=10$ wells). (G) Representative phase contrast images of colonies formed by shCtl and shER $\alpha$ knockout cells. Scale bars $=100 \mu \mathrm{m}$. Data for shCtl is shown in white and data for shER $\alpha$ is shown in grey. 
proliferation of shCtrl cells with shER $\alpha$ cells. Consistent with the effect of $1 \mu \mathrm{M}$ TPSF treatment, ER $\alpha$ knockdown led to a $27 \%$ decrease in the number of cells over 5 days (Fig. 3C). Strikingly, the impact of lowering the amount of $\mathrm{ER} \alpha$ in PTEN-deficient cells lead to a sustained reduction in the proliferation, demonstrated by a $76.5 \%$ decrease in the number of shER $\alpha$ cells compared to shCtrl cells over 5 passages (Fig. 3D). Once again, there was no difference in the cell viability (Supplementary Fig. 5). PTEN-deficient cells form colonies in Matrigel [35]; the ability of individual cells to form colonies is a measure of clonogenicity, whereas the size of each colony indicates their proliferative potential. Depletion of ER $\alpha$ did not change the number of colonies (Fig. 3E), but it led to a

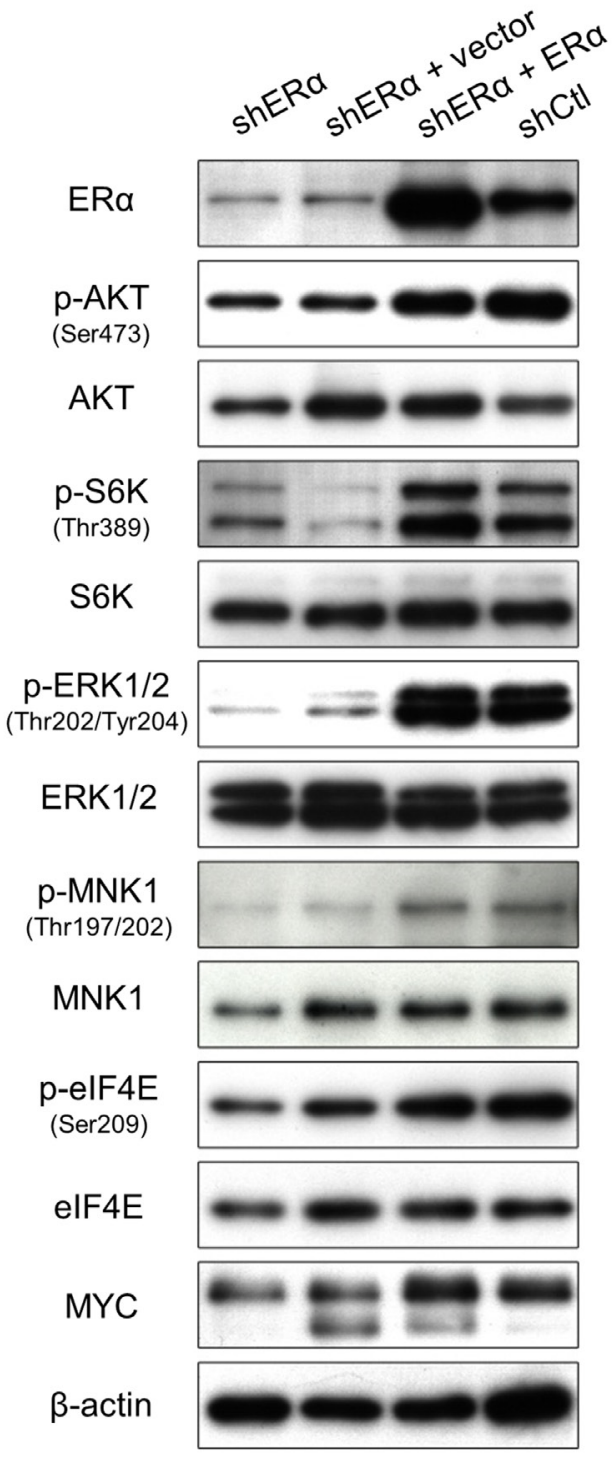

Figure 4: ER $\alpha$ regulates the activity of PI3K and MAPK signaling. Representative Western blots of components of the PI3K and MAPK signaling pathways in ER $\alpha$ knockdown $(\operatorname{shER} \alpha)$ and control (shCtl) PTEN-deficient cells. The shER $\alpha$ cells were also transfected with an empty vector (+ vector) or full length $E R \alpha$ construct ( $+E R \alpha$ ) for 3 days. significant decrease in the size of the colonies (Fig. 3F and $\mathrm{G})$. This confirms that $\mathrm{ER} \alpha$ regulates proliferation of prostate cancer cells.

\section{ERa sustains PI3K and MAPK signaling}

Since ER $\alpha$ stimulates PI3K and MAPK signaling, we hypothesized that the decrease in proliferation upon depletion of ER $\alpha$ was due to attenuated activity through these pathways. Therefore, we tested the phosphorylation status of key proteins in extracts from shCtrl cells, shER $\alpha$ cells and, to confirm that any changes in phosphorylation were dependent on ER $\alpha$ expression, shER $\alpha$ cells rescued by transfection with a shRNA-resistant ER $\alpha$ construct. The phosphorylation of AKT (mTORC2 site S473) and S6K (mTORC1 site T389), which are key proteins in the PI3K pathway, was reduced by ER $\alpha$ knockdown, demonstrating attenuated activity downstream of PI3K (Fig. 4). MAPK activity, assessed by phosphorylation of ERK1/2, MNK1 and eIF4E, was also dramatically inhibited by ER $\alpha$ depletion, as indicated by a substantial decrease in pERK1/2 and pMNK1 levels (Fig. 4). MYC is a critical regulator of cell proliferation and survival and its expression is regulated downstream of the PI3K and MAPK pathways which converge on eIF4E [36]. Accordingly, a decrease in MYC protein levels was observed in shER $\alpha$ cells (Fig. 4). Re-expression of ER $\alpha$ rescued $\mathrm{PI} 3 \mathrm{~K}$ and MAPK activity and restored MYC expression to the levels detected in shCtrl cells, confirming the specific action of ER $\alpha$. These data demonstrate that ER $\alpha$ sustains the activity of the PI3K and MAPK pathways in prostate cancer cells.

\section{$\mathrm{ER} \alpha$ transcriptome is enriched in metabolic genes}

The ER $\alpha$ transcriptome varies between cell types and tissues [37]. As little is known about the transcriptional effects of ER $\alpha$ in prostate epithelial cells, we used DNA microarrays to compare the mRNA abundance in shCtl and shER $\alpha$ cells. Analyses revealed that 1254 genes were up-regulated and 1078 were down-regulated following depletion of $\mathrm{ER} \alpha$ (fold-change $>1.5$ and False Discovery Rate $[\mathrm{FDR}]<0.1$ ). To assess the functional impact of these vast changes in steady state mRNA levels, we used a gene set enrichment approach to identify prominent functions among differentially regulated genes. Following filtering $(\mathrm{FDR}<0.15), 5$ pathways, all involved in cell division, were up-regulated in shER $\alpha$ versus shCtl cells (Supplementary Fig. 6). In contrast to the relatively few pathways identified among genes that are up-regulated in shERa cells, 51 pathways were enriched among those genes that were down-regulated. Notably, there was an overwhelming abundance of genes involved in carbohydrate metabolism (Table 1), suggesting that ER $\alpha$ modulates such processes either directly or indirectly. 


\section{ER $\alpha$ mediates sensitivity to glucose availability}

PTEN loss has been linked to resistance to caloric restriction in vivo [38] and increased glycolysis in vitro [39]. In addition, ER $\alpha$ stimulates glucose metabolism in breast cancer cells [40]. Therefore, we tested the impact of altering glucose concentration on the proliferation of shER $\alpha$ cells compared to shCtrl cells. The proliferation of shCtrl cells over three days in the absence of glucose was nearly halved ( $45.4 \%$ decrease) compared to shCtrl cells grown in high glucose medium (Fig. 5A). In contrast, $\operatorname{shER} \alpha$ cells were relatively less affected by the absence of glucose, displaying a $27.2 \%$ decrease in proliferation

A
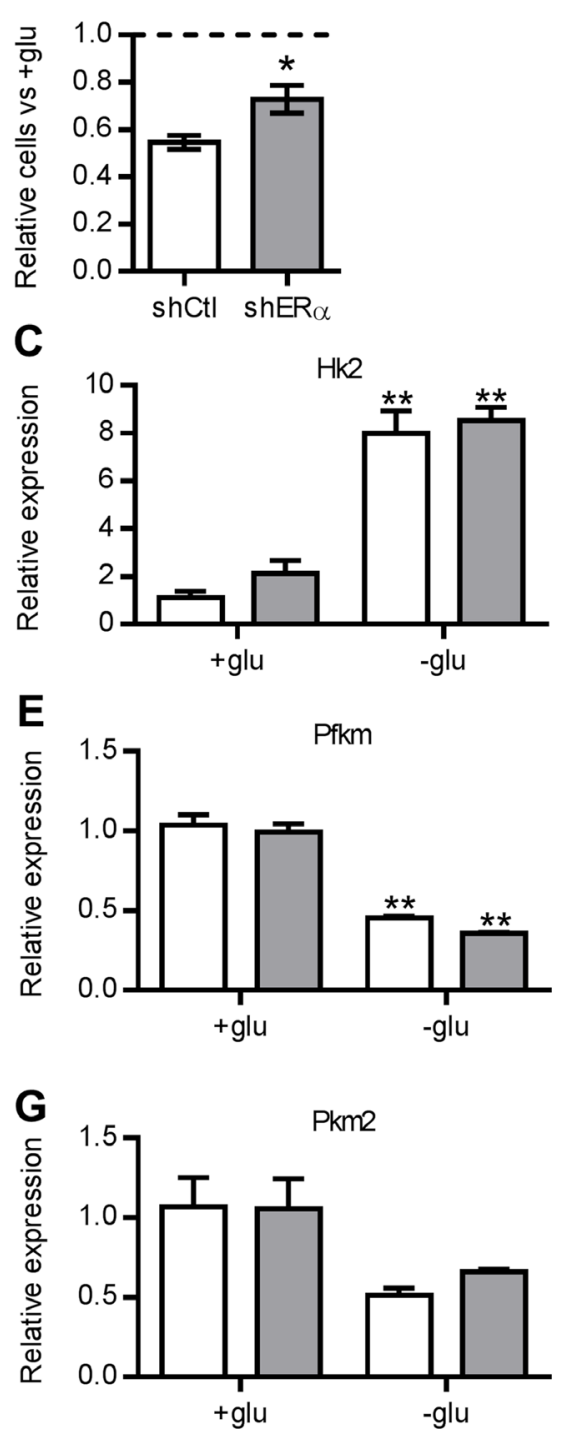

compared to shER $\alpha$ cells grown in high glucose medium. This difference in response to glucose withdrawal $(P<0.05)$ demonstrates that shCtrl cells are more dependent on glucose availability for proliferation compared to $\operatorname{shER} \alpha$ cells, presenting a potential mechanism whereby ER $\alpha$ over-expression may facilitate advanced prostate cancer growth. It is noteworthy that glucose deprivation led to a reduction in ER $\alpha$ mRNA compared to normal glucose conditions; however, the relative levels of $\mathrm{ER} \alpha$ in shCtl versus shER $\alpha$ cells were maintained with a $70-80 \%$ decrease in shER $\alpha$ cells (Fig. 5B).

Recently, a high throughput screen identified metabolic enzymes and small molecule transporters that confer glucose sensitivity to cancer cells grown in high

\section{B}
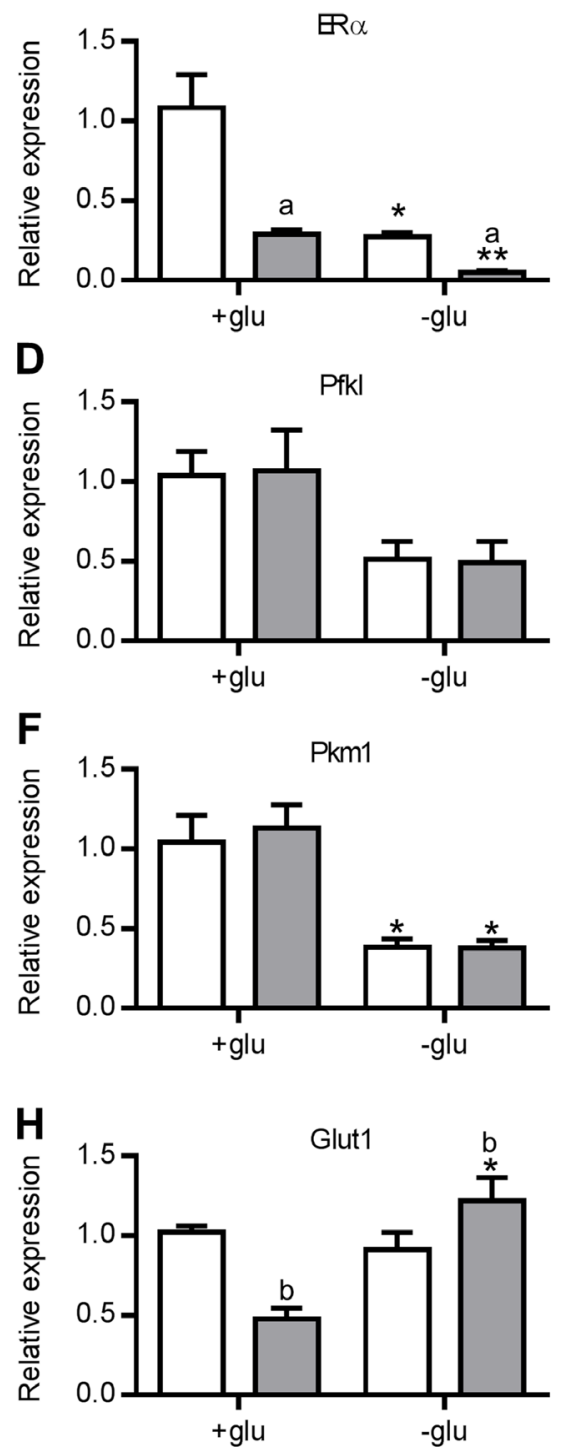

Figure 5: ER $\alpha$ mediates sensitivity to glucose availability. (A) Relative number of cells in shCtl (white) and shER $\alpha$ (grey) cells cultured in glucose-free media for 3 days. Data represents relative numbers of cells compared to media with glucose, represented by the dotted line ( $\mathrm{n}=3, * P<0.05$, T test). (B-G) Relative gene expression in shCtl (white) and shER $\alpha$ (grey) cells in cultured in basal (+glu) or glucose-free media for 3 days. Data represent relative gene expression normalized to shCtl cells in basal media $\left(\mathrm{n}=3\right.$, ${ }^{\mathrm{a} F D R}<0.05$, ${ }^{\mathrm{b}} \mathrm{FDR}<0.01$ for effect of shRNA; ${ }^{*} \mathrm{FDR}<0.05,{ }^{*} \mathrm{FDR}<0.01,1$ way post-test for the effect of glucose on each shRNA). 
Table 1: Down-regulated gene categories in $\operatorname{shER\alpha }$ cells related to small molecule metabolism

\begin{tabular}{|l|l|l|}
\hline p.val & q.val & Cellular functions \\
\hline $7.95 \mathrm{E}-06$ & 0.010 & cellular amino acid metabolic process \\
\hline $1.22 \mathrm{E}-05$ & 0.011 & mitochondrial inner membrane \\
\hline $2.29 \mathrm{E}-05$ & 0.015 & small molecule biosynthetic process \\
\hline $5.37 \mathrm{E}-05$ & 0.029 & carbon-carbon lyase activity \\
\hline 0.000324 & 0.081 & sterol biosynthetic process \\
\hline 0.000351 & 0.081 & deoxyribonucleotide catabolic process \\
\hline 0.000423 & 0.095 & glycosaminoglycan biosynthetic process \\
\hline 0.000462 & 0.099 & chondroitin sulfate biosynthetic process \\
\hline 0.000477 & 0.099 & glycosaminoglycan metabolic process \\
\hline 0.000546 & 0.110 & coenzyme metabolic process \\
\hline 0.000588 & 0.114 & deoxyribose phosphate catabolic process \\
\hline 0.000653 & 0.116 & single-organism carbohydrate catabolic process \\
\hline 0.000690 & 0.116 & cofactor metabolic process \\
\hline 0.000691 & 0.116 & hexose catabolic process \\
\hline 0.000778 & 0.120 & NADP metabolic process \\
\hline 0.000787 & 0.120 & proteoglycan biosynthetic process \\
\hline 0.000872 & 0.125 & monosaccharide catabolic process \\
\hline 0.000978 & 0.128 & generation of precursor metabolites and energy \\
\hline 0.001112 & 0.134 & carbohydrate catabolic process \\
\hline
\end{tabular}

or low glucose concentrations [41]. The factors giving a proliferative advantage in high glucose concentration were predominantly glycolytic enzymes. Therefore, we examined the relative expression of key enzymes catalyzing the three irreversible steps of glycolysis in shCtl and shER $\alpha$ cells (Fig. 5C-G). There was no significant difference in the expression of hexokinase $2(H k 2)$, phosphofructokinase $1(P f k l)$ and $\mathrm{m}(P f k m)$, or pyruvate kinase isoforms $(P \mathrm{~km} 1, P \mathrm{~km} 2)$ between shCtrl and shER $\alpha$ cells grown in high glucose. After glucose deprivation, the relative expression of $P f k l, P f k m$ and $P \mathrm{~km}$ isoforms was reduced (Fig. 5D-G), whereas the expression of $H k 2$ was increased 4-fold in both shCtrl and shER $\alpha$ cells, suggesting the cells are compensating by increasing hexose phosphorylation activity.

In contrast to the glycolytic enzymes, the glucose transporter Glut1 (Slc2al) was differentially regulated between shCtrl and shER $\alpha$ cells, consistent with the microarray analysis. Glut 1 was significantly up-regulated in shERa cells deprived of glucose (Fig. 5H), but unchanged in shCtrl cells. Since GLUT1 is the only small molecule transporter demonstrated to affect proliferation of cancer cells in low glucose [41], this striking difference in the regulation of Glut1 upon glucose deprivation could explain the lesser impact of glucose withdrawal on the proliferation of shER $\alpha$ cells. Collectively, these data show that ER $\alpha$ affects the sensitivity of prostate cancer cells to glucose withdrawal.

\section{DISCUSSION}

The autonomous role of $\mathrm{ER} \alpha$ in prostate cancer progression has largely been overlooked. This is due, in part, to confusion about the expression of ER $\alpha$ in prostate cancer. Previous immunohistochemistry studies reported differing levels of ER $\alpha$ in human prostate cancer cells [1117], possibly due to differences in the range of Gleason score tumors that were examined. We selected a cohort of Gleason score 6 and 9 tumors to ensure that low and high grade tumors were both represented. ER $\alpha$ was expressed in $48 \%$ of Gleason score 9 specimens, similar to an early study that detected ER $\alpha$ in $43-61 \%$ of Gleason grade 4-5 samples [11]. Another recent study reported that $15 \%$ of locally invasive tumours, spanning Gleason score 6 to 10 , expressed ER $\alpha$ and that it was significantly associated with biochemical recurrence, decreased progression free survival and poor overall survival [17]. In this study, we also showed that ER $\alpha$ is highly expressed in two different mouse models of aggressive prostate cancer, PTENdeficient and Hi-MYC mice, mirroring human disease. Together with the estrogenic gene expression signature reported by others [22], this confirms that ER $\alpha$ is indeed expressed in a subset of high grade prostate cancer.

It has long been difficult to study the autonomous actions of ER $\alpha$ in prostate cancer cells because of a paucity of experimental models. Fortunately, our data reveals that $\mathrm{ER} \alpha$ is expressed in mouse PTEN-deficient prostate cancer cells both in vivo and in vitro, making it a suitable model to study the role of ER $\alpha$ during prostate tumorigenesis and progression. Most human cell lines in contrast, express 
little or no ER $\alpha$, just as some lack the AR. NCI-H660 cells and some batches of PC3 cells express ER $\alpha$ [18-22], but are not ideal models because they lack AR and have a small cell rather than adenocarcinoma phenotype [42, 43]. Therefore, identifying new ER $\alpha$ human prostate cancer cell lines is a priority. Nevertheless, the ER $\alpha$ negative human prostate cancer cell lines have been useful in studying the mechanisms underlying ER $\alpha$ expression. The lack of $E R \alpha$ expression is due to hypermethylation of the ESR1 gene, rather than mutation or deletion [19-21]. This suggests that differential methylation could also underlie the re-activation of ER $\alpha$ expression in high grade human prostate cancer tissue. Since tumours with TMPRSS2-ERG fusions have an estrogen-regulated gene signature, it is also possible that re-activation of ER $\alpha$ expression is more common in this subset of tumours [22].

Prostate cancer is often considered to be slow growing and to have a low proliferative index, compared to other types of tumors. This is true of most cases of low to moderate grade disease, but a subset of high grade tumors are highly proliferative. Indeed, the percentage of Ki67 positive cells is a powerful prognostic indicator of poor clinical outcome [44]. The significant correlation between Ki67 and ER $\alpha$ staining in PTEN-deficient mice links ER $\alpha$ to rapidly proliferating, aggressive tumors. Importantly, $\mathrm{ER} \alpha$ not only correlated with proliferation, it regulated the proliferation of PTEN-deficient prostate cancer cells. This is consistent with a previous study showing that an $\mathrm{ER} \alpha$ agonist stimulates the proliferation of a small cell prostate cancer cell line, NCI-H660 [22]. Unexpectedly, even though ER $\alpha$ knockdown reduces the proliferation of PTEN-deficient cells, gene-set enrichment analyses showed that some pathways involved in the $M$ phase were up-regulated. This may represent a compensatory response, albeit insufficient, to the overall decrease in proliferation. Nevertheless, since ER $\alpha$ promotes the proliferation of prostate cancer cells, specifically inhibiting $\mathrm{ER} \alpha$ activity could be used to attenuate the growth of a subset of aggressive tumors.

Loss of PTEN is associated with progression to the most aggressive stages of prostate cancer [45]. Initial loss of one allele can be followed by complete lack of expression [29]. Loss of PTEN synergizes with loss of p53, overexpression of MYC and sustained activation of MAPK in promoting prostate cancer initiation and progression [30-32]. Our results demonstrate that ER $\alpha$ can regulate MYC expression upstream of the MAPK pathway. Considering that activating mutations in the RAS/RAF/ $\mathrm{MEK} / \mathrm{ERK}$ signaling cascade are rare in prostate cancer $[46,47]$, sustained stimulation of the MAPK pathway by $\mathrm{ER} \alpha$ is a potential mechanism to increase MYC expression in a subset of prostate cancers.

$\mathrm{ER} \alpha$ affects glucose metabolism in human breast cancer cells [40] and our data demonstrate that the same is true in mouse PTEN-deficient prostate cancer cells. Indeed, ER $\alpha$ knockdown decreased the expression of
Glut1 (SLC2A1). Highly proliferative PTEN-deficient tumour cells are often sensitive to decreases in glucose levels because they exhibit "glucose-addiction". In our model, this was attenuated by $\mathrm{ER} \alpha$ knockdown because the proliferation of $\operatorname{shER} \alpha$ cells was less affected by glucose withdrawal than shCtrl cells. The corollary is that PTEN-deficient prostate cancer cells expressing ER $\alpha$ are reliant on abundant glucose for their rapid proliferation.

In conclusion, we demonstrate that when ER $\alpha$ is expressed in prostate cancer cells it regulates proliferation, MYC expression and glucose sensitivity. The balance between glycolysis and OXPHOS in cancer cells has emerged as a major determinant of sensitivity to antidiabetic biguanides [41]. This is potentially all the more important considering that men taking metformin showed reduced prostate cancer specific mortality [48]. Further work will be required to determine the contribution of classical genomic and rapid non-genomic $\mathrm{ER} \alpha$ activities, and the specific contributions of ER $\alpha$ isoforms (66 and $46 \mathrm{kDa}$ splice variants), in regulating energy metabolism.

\section{METHODS}

\section{Patient Specimens}

Samples of formalin-fixed and paraffin embedded human prostate tissue, from 36 patients that had undergone radical prostatectomy, were obtained from the Australian Prostate Cancer BioResource with human ethics approval from ethics committees at Epworth Hospital (35906), Cabrini Hospital (10-13-12-04) and Monash University (2005-442). An experienced Uropathologist (J.P.) determined the Gleason Score and percentage of tumor cells expressing ER $\alpha$ in each specimen. Positive ER $\alpha$ staining of tumor cells was defined as prominent nuclear immunoreactivity compared to negative $\operatorname{ER} \alpha$ staining in nearby benign glands.

\section{Animals}

ARR2/Pbsn-Myc (Hi-MYC) mice were obtained from NCI-Frederick, VA, USA and housed and humanely killed according to Monash University animal ethics approval. The lateral prostate was harvested from 32 week old Hi-MYC mouse or age-matched control mice. PBi-Cre transgenic mice [49] were crossed with Pten floxed animals [50] to specifically deplete Pten within the prostate epithelium. Animals were maintained on a mixed 129:fvb/n background. Pten-deficient $\left(\mathrm{PBiCre}^{+/-} ; \mathrm{Pten}^{\mathrm{f} / \mathrm{fl}}\right)$ and control mice $\left(\mathrm{PBiCr}^{+-}\right)$were used at $80-100 \mathrm{~d}$ of age for all studies. Experiments were performed according to animal ethics approval from the Peter MacCallum Cancer Centre. 


\section{Immunohistochemistry}

Immunohistochemistry was performed manually with the DAKO EnVision+ detection system or with an autostainer using the Leica BOND-MAX system (Leica Microsystems Pty. Ltd.). The concentration and specific conditions for each primary antibody are listed in Supplementary Table 2. The specificity of the ER $\alpha$ antibody has been confirmed by several independent laboratories [11, 12, 51].

\section{Stereology}

Slides of stained tissues were imaged with an Aperio ScanScope digital scanner and viewed using ImageScope software (Aperio). The dorsal, lateral and ventral lobes were divided into benign and malignant foci. Within the anterior prostate, tumor foci were divided into peripheral tumor regions, within $50 \mu \mathrm{m}$ of the stroma, and central tumor regions greater than $100 \mu \mathrm{m}$ from the stroma. The percentage of ER $\alpha$ or Ki67 positive cells was manually counted in at least 3 fields per region (average $\sim 10$ fields) for 3 mice. Each field contained an average of approximately 150 cells. Data is represented as the average percentage of positively stained cells in each region per mouse.

\section{Cell Culture}

MCF7 cells were purchase from the American Type Culture Collection and cultured in RPMI medium containing 5\% fetal bovine serum (FBS), $100 \mathrm{IU} / \mathrm{ml}$ penicillin and $10 \mu \mathrm{g} / \mathrm{ml}$ streptomycin (Invitrogen). An epithelial prostate cancer cell line was established from an invasive prostate carcinoma harvested from a 407 day old male $\mathrm{PBiCre}{ }^{+/} ; \mathrm{Pten}^{\text {t/fl}}$ mouse. Briefly, prostate tumor sections approximately $5 \mathrm{~mm}^{3}$ were placed on ice for $1 \mathrm{hr}$ in PBS supplemented with 3\% penicillin streptomyocin (Pen Strep, Gibco) prior to homogenization. Samples were then transferred to a T25 flask with $5 \mathrm{ml}$ of $\alpha$-MEM medium containing $20 \%$ FBS, $1 \%$ soduim pyruvate, 80 $\mu \mathrm{g} / \mathrm{ml}$ Fluconazole, 1\% Pen Strep and 1\% Glutamate (Gibco). Media was replaced every 2-3 days. Cultures were then maintained in high glucose DMEM medium containing $10 \% \mathrm{FBS}, 100 \mathrm{IU} / \mathrm{ml}$ penicillin and $10 \mu \mathrm{g} /$ $\mathrm{ml}$ streptomycin (Invitrogen) and kept in a humidified incubator at $37^{\circ} \mathrm{C}$ with $5 \% \mathrm{CO}_{2}$.

\section{Estrogen antagonist treatments}

PTEN-deficient prostate cancer cells were seeded in 6 well plates $\left(2 \times 10^{4} /\right.$ well $)$ and cultured for $24 \mathrm{~h}$. Cells were then treated daily for 4 days with media containing DMSO or $1 \mu \mathrm{M}$ TPSF (p-fluoro-4-(1,2,3,6,-tetrahydro- 1,3-dimethyl-2-oxo-6-thionpurin-8-ylthio). On the fifth day, cells were trypsinized, resuspended in media and counted using a TC10 automated cell counter (BioRad). The experiment was performed three times in triplicate.

\section{ERa Knockdown}

Knockdown experiments were performed using the pGIPZ vector (Open Biosystems) containing either a non-silencing control shRNA or a mouse ER $\alpha$ shRNA (V2LMM_30677). Viral stocks were prepared from 293$\mathrm{T}$ cells using the Trans-Lentiviral shRNA Packaging kit according to the manufacturer's instructions. PTENdeficient cells were transduced, sorted for GFP expression and then maintained in medium supplemented with $4 \mu \mathrm{g} /$ $\mathrm{mL}$ puromycin.

\section{Proliferation Assays}

To assess proliferation, $2 \times 10^{4}$ cells were seeded per well in 6-well plates and cultured for 1, 3 or 5 days before being trypsinized and counted using a TC10 automated cell counter (BioRad). For all cell counts, trypan blue was used to measure cell viability, which was typically between $97-100 \%$ and was not affected by any treatment. Therefore, all data are reported as numbers of viable cells. Cumulative differences in proliferation were measured by seeding, counting and re-seeding $5 \times 10^{4}$ cells every 4 days for 5 passages. The proliferation of cells in three dimensional conditions was measured by seeding 3000 cells in $100 \mu \mathrm{L}$ of a 2:3 mixture of media to growth factorreduced Matrigel (BD Biosciences). The solution was set around the edge of the wells of a 12-well plate and the cells were cultured for 10 days. The number of colonies was counted with a phase contrast microscope at 20 times magnification. The size of colonies was measured using ImageJ with images taken at 4 positions per well, typically containing a total of 20-30 colonies.

\section{ER $\alpha$ Rescue}

To rescue full length ER $\alpha$ expression, $1 \times 10^{5}$ PTENdeficient cells were seeded per well in 6 well plates for $24 \mathrm{hr}$ and then transfected with $2.5 \mu \mathrm{g}$ of a human ER $\alpha 66$ construct (pSG5-HEGO) or empty vector control using $12.5 \mu \mathrm{l} /$ well of lipofectamine 2000. Cells were harvested after $72 \mathrm{hrs}$.

\section{Western blotting}

Samples were lysed in RIPA buffer containing $5 \mathrm{mM}$ $\mathrm{NaF}, 1 \mathrm{mM} \mathrm{Na} \mathrm{VO}_{4}$ and $1 \mathrm{x}$ complete protease inhibitor cocktail (Roche) and quantified using the bicinchoninic acid assay (Promega). Lysates were separated using 
polyacrylamide gel electrophoresis and probed with primary antibodies listed in Supplementary Table 1. Membranes were then incubated with HRP-conjugated secondary antibodies (goat anti-rabbit, goat anti-mouse (Dako), goat anti-rat (Cell Signaling)) followed by ECL Plus Western Blotting Detection Reagent (GE Healthcare).

\section{Microarrays}

Cells were lysed in hypotonic lysis buffer $(5 \mathrm{mM}$ Tris-HCl [pH7.5], 2.5 mM MgCl2, 1.5 mM KCl, $100 \mu \mathrm{g} /$ $\mathrm{ml}$ cycloheximide, $2 \mathrm{mM}$ DTT, $0.5 \%$ Triton $\mathrm{X}-100$, and $0.5 \%$ sodium deoxycholate), supernatant was cleared by centrifugation and total RNA was isolated using TRIzol Reagent (Life Technologies). RNA from biological triplicate experiments were labelled according to the manufacturer's guidelines (Affymetrix), hybridized to the Affymetrix Gene ST 1.1 Gene Titan array and scanned using the Affymetrix GeneTitan scanner. The resulting .CEL files were normalized using updated probe set definitions [52], because these provide improved precision and accuracy as compared to the default probe set definitions [53], and the robust multi-array average (RMA) algorithm [54] using the "affy" R (r-project.org) package. Differential expression was identified using the random variance model t-statistics [55] and the resulting p-values were adjusted using the Benjamini-Hochberg False Discovery Rate (FDR) method [56]. Genes with an $\mathrm{FDR}<0.1$ and a fold-change $>\log 2(1.5)$ were considered significantly differentially expressed. To identify functions enriched among genes at the ends of a gene list ranked by signed (up[+] or down[-]) - $\log 10$ (p-values), we used GAGE [57] and annotations from the gene ontology consortium [58]. Within the "gage" function we used rank. test=TRUE and default settings (i.e. categories containing between 10 and 500 genes were considered). Categories with an FDR $<0.1$ were considered significant enriched.

\section{Glucose Deprivation}

Cells were seeded at $2 \times 10^{4}$ cells per well in 6 well plates in standard high glucose $(25 \mathrm{mM})$ DMEM medium containing 10\% FBS, $100 \mathrm{IU} / \mathrm{ml}$ penicillin and $10 \mu \mathrm{g} / \mathrm{ml}$ streptomycin (Invitrogen). After $24 \mathrm{hr}$, the medium was changed to standard high glucose medium or glucosefree DMEM, both containing 10\% FBS and antibiotics. After 3 days, the cells were trypsinized and counted using an automated cell counter. Data was normalized to the average number of cells in high glucose medium. The experiment was repeated 4 times in triplicate.

\section{RNA extraction and quantitative RT-PCR}

Total RNA was extracted using an RNeasy kit (Qiagen) and treated with DNase I according to the manufacturer's instructions (Life Technologies). Complementary DNA was synthesized using the SuperScript III First Strand Synthesis System (Life Technologies). Samples were amplified using Power Sybr Green (Life Technologies) and gene-specific primers (Sigma Aldrich; Supplementary Table 3) on an ABI7900 thermocycler (Life Technologies). Target genes were normalized to the geometric mean of three reference genes, RPLP0, HPRT1 and UBC. Relative gene expression was calculated using the delta delta $\mathrm{Ct}$ method.

\section{Statistical Analyses}

GraphPad Prism software was used to generate graphs and perform statistical analyses, which are noted in figure legends. All data are displayed with standard error of the mean calculated from independent experiments.

\section{ACKNOWLEDGEMENTS}

We gratefully acknowledge the expert assistance of Birunthi Niranjan, Michelle Richards, Shelley Hedwards and Melissa Papargiris.

\section{Financial Support}

Funding was obtained from the National Health and Medical Research Council (Enabling Grant to APCB: 614296, Fellowship to GR: 1002648, Project Grant: 1020959, Fellowship to ML: 1035721, Fellowship to MW: 606460), Prostate Cancer Foundation of Australia (Infrastructure grant to APCB; Movember Young Investigator Grants to RT, ML, LF and HP) and Australian Research Council (DECRA Fellowship to LF: DE120100434). EG supported by MICRTP Studentship. OL is funded by the Swedish Research Council, the Swedish Cancer Foundation and the Wallenberg Academy Fellows program. HP is supported by a Richard Pratt Foundation Fellowship for Prostate Cancer Research.

\section{Conflicts of Interest}

The authors do not have any conflicts of interest to report.

\section{REFERENCES}

1. Siegel R, Ma J, Zou Z and Jemal A. Cancer statistics, 2014. CA Cancer J Clin. 2014; 64(1):9-29. 
2. Travison TG, Araujo AB, Kupelian V, O'Donnell AB and McKinlay JB. The relative contributions of aging, health, and lifestyle factors to serum testosterone decline in men. $\mathrm{J}$ Clin Endocrinol Metab. 2007; 92(2):549-555.

3. Risbridger GP, Davis ID, Birrell SN and Tilley W. Breast and prostate cancer: more similar than different. Nature Review Cancer. 2010; 10(3):205-212.

4. Ricke WA, McPherson SJ, Bianco JJ, Cunha GR, Wang $\mathrm{Y}$ and Risbridger GP. Prostatic hormonal carcinogenesis is mediated by in situ estrogen production and estrogen receptor alpha signaling. FASEB J. 2008; 22(5):1512-1520.

5. Wang Y, Sudilovsky D, Zhang B, Haughney PC, Rosen MA, Wu DS, Cunha TJ, Dahiya R, Cunha GR and Hayward SW. A human prostatic epithelial model of hormonal carcinogenesis. Cancer Res. 2001; 61(16):6064-6072.

6. Ellem SJ and Risbridger GP. Treating prostate cancer: a rationale for targeting local oestrogens. Nat Rev Cancer. 2007; 7(8):621-627.

7. Sugiyama N, Barros RP, Warner M and Gustafsson JA. ERbeta: recent understanding of estrogen signaling. Trends Endocrinol Metab. 2010; 21(9):545-552.

8. Hussain S, Lawrence MG, Taylor RA, Lo CY, Frydenberg M, Ellem SJ, Furic L and Risbridger GP. Estrogen receptor beta activation impairs prostatic regeneration by inducing apoptosis in murine and human stem/progenitor enriched cell populations. PLoS ONE. 2012; 7(7):e40732.

9. McPherson SJ, Hussain S, Balanathan P, Hedwards SL, Niranjan B, Grant M, Chandrasiri UP, Toivanen R, Wang Y, Taylor RA and Risbridger GP. Estrogen receptor-beta activated apoptosis in benign hyperplasia and cancer of the prostate is androgen independent and TNFalpha mediated. Proc Natl Acad Sci U S A. 2010; 107(7):3123-3128.

10. Mak P, Leav I, Pursell B, Bae D, Yang X, Taglienti CA, Gouvin LM, Sharma VM and Mercurio AM. ERbeta impedes prostate cancer EMT by destabilizing HIF-1alpha and inhibiting VEGF-mediated snail nuclear localization: implications for Gleason grading. Cancer Cell. 2010; 17(4):319-332.

11. Bonkhoff H, Fixemer $T$, Hunsicker $I$ and Remberger $\mathrm{K}$. Estrogen receptor expression in prostate cancer and premalignant prostatic lesions. Am J Pathol. 1999; 155(2):641-647.

12. Leav I, Lau, K. M, Adams, J. Y, McNeal, J. E, Taplin, M. E, Wang, J, Singh, H, Ho, S. M. Comparative studies of the estrogen receptors beta and alpha and the androgen receptor in normal human prostate glands, dysplasia, and in primary and metastatic carcinoma. Am J Pathol. 2001; 159(1):79-92.

13. Royuela M, de Miguel MP, Bethencourt FR, SanchezChapado M, Fraile B, Arenas MI and Paniagua R. Estrogen receptors alpha and beta in the normal, hyperplastic and carcinomatous human prostate. J Endocrinol. 2001; 168(3):447-454.

14. Hobisch A, Hittmair A, Daxenbichler G, Wille S, Radmayr C, Hobisch-Hagen P, Bartsch G, Klocker H and Culig Z.
Metastatic lesions from prostate cancer do not express oestrogen and progesterone receptors. J Pathol. 1997; 182(3):356-361.

15. Celhay O, Yacoub M, Irani J, Dore B, Cussenot O and Fromont G. Expression of estrogen related proteins in hormone refractory prostate cancer: association with tumor progression. J Urol. 2010; 184(5):2172-2178.

16. Hetzl AC, Montico F, Lorencini RM, Kido L, Candido E, Billis A, Ferreira U and Cagnon VH. Fibroblast growth factor, estrogen, and prolactin receptor features in different grades of prostatic adenocarcinoma in elderly men. Microsc Res Tech. 2013; 76(3):321-330.

17. Megas G, Chrisofos M, Anastasiou I, Tsitlidou A, Choreftaki $\mathrm{T}$ and Deliveliotis C. Estrogen receptor (alpha and beta) but not androgen receptor expression is correlated with recurrence, progression and survival in post prostatectomy T3N0M0 locally advanced prostate cancer in an urban Greek population. Asian J Androl. 2014.

18. Linja MJ, Savinainen KJ, Tammela TL, Isola JJ and Visakorpi T. Expression of ERalpha and ERbeta in prostate cancer. Prostate. 2003; 55(3):180-186.

19. Sasaki M, Tanaka Y, Perinchery G, Dharia A, Kotcherguina I, Fujimoto S and Dahiya R. Methylation and inactivation of estrogen, progesterone, and androgen receptors in prostate cancer. J Natl Cancer Inst. 2002; 94(5):384-390.

20. Li LC, Chui R, Nakajima K, Oh BR, Au HC and Dahiya R. Frequent methylation of estrogen receptor in prostate cancer: correlation with tumor progression. Cancer Res. 2000; 60(3):702-706.

21. Lau KM, LaSpina M, Long J and Ho SM. Expression of estrogen receptor (ER)-alpha and ER-beta in normal and malignant prostatic epithelial cells: regulation by methylation and involvement in growth regulation. Cancer Res. 2000; 60(12):3175-3182.

22. Setlur SR, Mertz KD, Hoshida Y, Demichelis F, Lupien M, Perner S, Sboner A, Pawitan Y, Andren O, Johnson LA, Tang J, Adami HO, Calza S, Chinnaiyan AM, Rhodes $\mathrm{D}$, Tomlins S, et al. Estrogen-dependent signaling in a molecularly distinct subclass of aggressive prostate cancer. J Natl Cancer Inst. 2008; 100(11):815-825.

23. McDevitt MA, Glidewell-Kenney C, Jimenez MA, Ahearn PC, Weiss J, Jameson JL and Levine JE. New insights into the classical and non-classical actions of estrogen: evidence from estrogen receptor knock-out and knock-in mice. Mol Cell Endocrinol. 2008; 290(1-2):24-30.

24. Parsons S, Pritchard J, Fox E and Shupnik M. (2012). Cooperative Interactions Between c-Src, Estrogen Receptors and Receptor Tyrosine Kinases in Breast Cancer. In: Castoria G and Migliaccio A, eds. Advances in Rapid Sex-Steroid Action: Springer New York), pp. 31-59.

25. Pandini G, Genua M, Frasca F, Squatrito S, Vigneri R and Belfiore A. 17beta-estradiol up-regulates the insulin-like growth factor receptor through a nongenotropic pathway in prostate cancer cells. Cancer Res. 2007; 67(18):8932-8941. 
26. Simoncini T, Hafezi-Moghadam A, Brazil DP, Ley K, Chin WW and Liao JK. Interaction of oestrogen receptor with the regulatory subunit of phosphatidylinositol-3-OH kinase. Nature. 2000; 407(6803):538-541.

27. Shupnik MA. Crosstalk between steroid receptors and the c-Src-receptor tyrosine kinase pathways: implications for cell proliferation. Oncogene. 2004; 23(48):7979-7989.

28. Phin S, Moore MW and Cotter PD. Genomic Rearrangements of PTEN in Prostate Cancer. Front Oncol. 2013; 3:240.

29. Sircar K, Yoshimoto M, Monzon FA, Koumakpayi IH, Katz RL, Khanna A, Alvarez K, Chen G, Darnel AD, Aprikian AG, Saad F, Bismar TA and Squire JA. PTEN genomic deletion is associated with p-Akt and AR signalling in poorer outcome, hormone refractory prostate cancer. J Pathol. 2009; 218(4):505-513.

30. Wang J, Kobayashi T, Floc'h N, Kinkade CW, Aytes A, Dankort D, Lefebvre C, Mitrofanova A, Cardiff RD, McMahon M, Califano A, Shen MM and Abate-Shen C. B-Raf activation cooperates with PTEN loss to drive c-Myc expression in advanced prostate cancer. Cancer Res. 2012; 72(18):4765-4776.

31. Chen Z, Trotman LC, Shaffer D, Lin HK, Dotan ZA, Niki M, Koutcher JA, Scher HI, Ludwig T, Gerald W, CordonCardo C and Pandolfi PP. Crucial role of p53-dependent cellular senescence in suppression of Pten-deficient tumorigenesis. Nature. 2005; 436(7051):725-730.

32. Kim J, Roh M, Doubinskaia I, Algarroba GN, Eltoum IE and Abdulkadir SA. A mouse model of heterogeneous, c-MYC-initiated prostate cancer with loss of Pten and p53. Oncogene. 2012; 31(3):322-332.

33. Wang S, Garcia AJ, Wu M, Lawson DA, Witte ON and Wu H. Pten deletion leads to the expansion of a prostatic stem/ progenitor cell subpopulation and tumor initiation. Proc Natl Acad Sci U S A. 2006; 103(5):1480-1485.

34. Kretzer NM, Cherian MT, Mao C, Aninye IO, Reynolds PD, Schiff R, Hergenrother PJ, Nordeen SK, Wilson EM and Shapiro DJ. A noncompetitive small molecule inhibitor of estrogen-regulated gene expression and breast cancer cell growth that enhances proteasome-dependent degradation of estrogen receptor \{alpha\}. J Biol Chem. 2010; 285(53):41863-41873.

35. Mulholland DJ, Xin L, Morim A, Lawson D, Witte O and Wu H. Lin-Sca-1+CD49fhigh stem/progenitors are tumorinitiating cells in the Pten-null prostate cancer model. Cancer Res. 2009; 69(22):8555-8562.

36. Lin CJ, Malina A and Pelletier J. c-Myc and eIF4F constitute a feedforward loop that regulates cell growth: implications for anticancer therapy. Cancer Res. 2009; 69(19):7491-7494.

37. Krum SA, Miranda-Carboni GA, Lupien M, Eeckhoute J, Carroll JS and Brown M. Unique ERalpha cistromes control cell type-specific gene regulation. Mol Endocrinol. 2008; 22(11):2393-2406.
38. Kalaany NY and Sabatini DM. Tumours with PI3K activation are resistant to dietary restriction. Nature. 2009; 458(7239):725-731.

39. Blouin MJ, Zhao Y, Zakikhani M, Algire C, Piura E and Pollak M. Loss of function of PTEN alters the relationship between glucose concentration and cell proliferation, increases glycolysis, and sensitizes cells to 2-deoxyglucose. Cancer Lett. 2010; 289(2):246-253.

40. O’Mahony F, Razandi M, Pedram A, Harvey BJ and Levin ER. Estrogen modulates metabolic pathway adaptation to available glucose in breast cancer cells. Mol Endocrinol. 2012; 26(12):2058-2070.

41. Birsoy K, Possemato R, Lorbeer FK, Bayraktar EC, Thiru P, Yucel B, Wang T, Chen WW, Clish CB and Sabatini DM. Metabolic determinants of cancer cell sensitivity to glucose limitation and biguanides. Nature. 2014; 508(7494):108112.

42. Tai S, Sun Y, Squires JM, Zhang H, Oh WK, Liang CZ and Huang J. PC3 is a cell line characteristic of prostatic small cell carcinoma. Prostate. 2011; 71(15):1668-1679.

43. Mertz KD, Setlur SR, Dhanasekaran SM, Demichelis F, Perner S, Tomlins S, Tchinda J, Laxman B, Vessella RL, Beroukhim R, Lee C, Chinnaiyan AM and Rubin MA. Molecular characterization of TMPRSS2-ERG gene fusion in the NCI-H660 prostate cancer cell line: a new perspective for an old model. Neoplasia. 2007; 9(3):200-206.

44. Fisher G, Yang ZH, Kudahetti S, Moller H, Scardino P, Cuzick J, Berney DM and Transatlantic Prostate G. Prognostic value of Ki-67 for prostate cancer death in a conservatively managed cohort. Br J Cancer. 2013; 108(2):271-277.

45. Shtivelman E, Beer TM and Evans CP. Molecular pathways and targets in prostate cancer. Oncotarget. 2014; 5(17):7217-7259.

46. Cho NY, Choi M, Kim BH, Cho YM, Moon KC and Kang GH. BRAF and KRAS mutations in prostatic adenocarcinoma. Int J Cancer. 2006; 119(8):1858-1862.

47. Kollermann J, Albrecht H, Schlomm T, Huland H, Graefen M, Bokemeyer C, Simon R, Sauter G and Wilczak W. Activating BRAF gene mutations are uncommon in hormone refractory prostate cancer in Caucasian patients. Oncol Lett. 2010; 1(4):729-732.

48. Margel D, Urbach DR, Lipscombe LL, Bell CM, Kulkarni G, Austin PC and Fleshner N. Metformin use and all-cause and prostate cancer-specific mortality among men with diabetes. J Clin Oncol. 2013; 31(25):3069-3075.

49. Jin $\mathrm{C}, \mathrm{McKeehan} \mathrm{K}$ and Wang F. Transgenic mouse with high Cre recombinase activity in all prostate lobes, seminal vesicle, and ductus deferens. Prostate. 2003; 57(2):160-164.

50. Lesche R, Groszer M, Gao J, Wang Y, Messing A, Sun $\mathrm{H}$, Liu $\mathrm{X}$ and $\mathrm{Wu} \mathrm{H}$. Cre/loxP-mediated inactivation of the murine Pten tumor suppressor gene. Genesis. 2002; 32(2):148-149.

51. Bevitt DJ, Milton ID, Piggot N, Henry L, Carter MJ, 
Toms GL, Lennard TW, Westley B, Angus B and Horne $\mathrm{CH}$. New monoclonal antibodies to oestrogen and progesterone receptors effective for paraffin section immunohistochemistry. J Pathol. 1997; 183(2):228-232.

52. Dai M, Wang P, Boyd AD, Kostov G, Athey B, Jones EG, Bunney WE, Myers RM, Speed TP, Akil H, Watson SJ and Meng F. Evolving gene/transcript definitions significantly alter the interpretation of GeneChip data. Nucleic Acids Res. 2005; 33(20):e175.

53. Sandberg $\mathrm{R}$ and Larsson O. Improved precision and accuracy for microarrays using updated probe set definitions. BMC Bioinformatics. 2007; 8:48.

54. Irizarry RA, Hobbs B, Collin F, Beazer-Barclay YD, Antonellis KJ, Scherf $U$ and Speed TP. Exploration, normalization, and summaries of high density oligonucleotide array probe level data. Biostatistics. 2003; 4(2):249-264.

55. Wright GW and Simon RM. A random variance model for detection of differential gene expression in small microarray experiments. Bioinformatics. 2003; 19(18):2448-2455.

56. Benjamini $\mathrm{Y}$ and Hochberg $\mathrm{Y}$. Controlling the False Discovery Rate: A Practical and Powerful Approach to Multiple Testing. Journal of the Royal Statistical Society Series B (Methodological. 1995; 57(1):289-300.

57. Luo W, Friedman MS, Shedden K, Hankenson KD and Woolf PJ. GAGE: generally applicable gene set enrichment for pathway analysis. BMC Bioinformatics. 2009; 10:161.

58. Gene Ontology C, Blake JA, Dolan M, Drabkin H, Hill DP, Li N, Sitnikov D, Bridges S, Burgess S, Buza T, McCarthy F, Peddinti D, Pillai L, Carbon S, Dietze H, Ireland A, et al. Gene Ontology annotations and resources. Nucleic Acids Res. 2013; 41(Database issue):D530-535. 